\title{
Effect of high pressure processing on meat and meat products. A review
}

Valerii Sukmanovi, Ma Hanjun², Yan-ping Li1, 2

\author{
1 - Sumy National Agrarian University, Sumy, Ukraine \\ 2 - Henan Institute of Science and Technology, Xinxiang, PR China
}

\section{Keywords:}

Pressure

Meat

Texture

Protein

Gel

\section{Article history:}

Received 20.12.2018

Received in revised

form 15.04.2019

Accepted 30.09.2019

\section{Corresponding}

author:

Valerii Sukmanov

E-mail:

sukmanovvaleri@

gmail.com

DOI: $10.24263 / 2304-$

974X-2019-8-3-4

\section{Abstract}

Abstract. High pressure processing of meat is considered the best non-thermal processing technology to prolong the shelf life and safety of meat, semifinished meat and ready-to-eat meat products preserving sensory and nutritional properties.

Material and methods. The object of the paper is properties of meat, minced meat products, gel and protein conformation of myofibrillar proteins treated with high pressure. The research method is the analysis and synthesis of the latest study of the world's leading scientific journals.

Result and discussion. During high pressure processing, pressure level is 100-1000 MPa and temperature range is $-20{ }^{\circ} \mathrm{C}$ to $90{ }^{\circ} \mathrm{C}$. The relevance and perspectiveness of the research of the use of high pressure technology in the meat industry have been proved on the basis of the analysis of the principle of high pressure processing of meat and meat products, the i MPact of high pressure on: muscle features ( $\mathrm{pH}$, colour, texture, tenderness and water-holding capacity); minced meat products (water- and fat- holding capacity, texture); quality features of gel and protein conformation of myofibrillar proteins (water- and fat- holding capacity of myofibrillar proteins, covalent and noncovalent bonds, protein conformation of myofibrillar proteins).

High pressure processing improves features of muscle, minced meat products and myofibrillar proteins. The application of moderate pressure treatment to prerigor meat maintains the colour and tenderness. High pressure treatment can increase water-and fat holding capacity and texture of minced meat. High pressure also affects on covalent and noncovalent bonds and protein conformation of myofibrillar proteins, develops water-holding capacity, improves texture of myofibrilla proteins.

Conclusion. The use of high pressure processing technology in the meat industry is important and promising. However, the effect of factors on muscle properties, minced meat and myofibrillar proteins when using high pressure is very complex and it should be studied further. 


\section{Contents of the Review}

Introduction.

1. Relevance and prospects of using high pressure technology in the meat industry.

2. Principle of high pressure processing and high pressure process equipment.

3. Effects of high pressure processing on the properties of muscle.

3.1. Effects of high pressure processing on the $\mathrm{pH}$ of muscle.

3.2. Effects of high pressure processing on the color of meat.

3.3. Effects of high pressure processing on the water holding capacity of muscle.

3.4. Effects of high pressure processing on the tenderness of muscle.

4. Effect of high pressure on the comminuted meat products.

4.1. Effect of high pressure on the water and fat holding capacity of comminuted meat products.

4.2. Effect of high pressure on the texture of comminuted meat products.

5. Effect of high pressure on the gel properties and protein conformation of myofibrillar proteins.

5.1. Effect of high pressure on the water holding capacity of myofibrillar proteins.

5.2. Effect of high pressure on the texture of myofibrillar proteins.

5.3. Effect of high pressure on the non-covalent bond, covalent bond and protein conformation of myofibrillar proteins.

Conclusion.

\section{Introduction}

High pressure processing (HPP), can be referred to as ultra high pressure technology or hydrostatic technology, the water or other incompressible fluid mediums often act as mediators of pressure. During the high pressure processing, the pressure levels generally not less than $100 \mathrm{MPa}$, the commonly used range is $100-1000 \mathrm{MPa}$ and can work in the temperature range of $-20{ }^{\circ} \mathrm{C}$ to $90{ }^{\circ} \mathrm{C}$. After the food is sealed in an elastic container or placed in a pressure system, the non-covalent bonds (hydrogen bonds, ionic bonds and hydrophobic bonds, etc.) are been destroyed or formed at a certain temperature for the appropriate processing time and pressure level, which cited the enzyme in food, protein, starch and other biological high molecular substances are deactivated, denatured and gelatinized respectively, and kill the microorganism in food biological, so as to achieve the purpose of food sterilization, preservation and processing.

The ability of high pressures to inactivate micro organisms and denature proteins has been known for over one hundred years. Food high pressure processing technology was began at the end of the 19th century, and the first application of high pressure technology in the field of food is started in food sterilization. In 1895, H. Rouer had carried out the research on killing bacteria with high pressure technology. Hite used high pressure to treat and process milk and meat products in 1899 , found that $450 \mathrm{MPa}$ or beyond could prolong the storage life of milk, and put forward the possibility that high pressure can be used as food processing method for the first time. Due to the difficults of technology, the commercial application of high pressure processing in food until to the 1980s with the development of rigs capable of processing reasonably large volumes. Initial success was with fruit based products such as orange juice and avocado paste (guacamole) could be stored for several weeks at refrigeration temperatures with no discernable loss of quality after around $500 \mathrm{MPa}$ treated, because of both bacteria and enzymes were fully or partially inactivated. Since that time many more products have appeared on the market with varying degrees of success. 


\section{Relevance and prospects of using high pressure technology in the meat industry}

High pressure processing is basically a physical process and using a liquid media. Which has the advantages of pressure uniform transmission, instantaneous, efficient, low energy consumption, pollution little dyeing, and no obvious effects of low molecular compounds such as Vitamins, pigments and flavor substances, etc. Therefore, high pressure technology can develop the appearance and new types of meat with different textures will be available in meat processing and storage. At present, the application of high pressure technology in meat processing mainly includes improving meat quality, sterilization and freezing and thawing meat, such as improve meat tenderness, water- and fat- holding capacity, fat oxidation, gel properties. However, in order to realize the large-scale application of high pressure technology in meat processing, there are still many problems worthy of indepth discussion, and the research on these problems may be the key consideration in the future. Firstly, the high pressure equipment needs a high investment, which has to solve the problem of high cost, which seriously restricts the promotion of industrialization. Secondly, the affecting factors of high pressure processing is complex and diverse, including pressure levels, time, temperature, pressure and the characteristics of raw materials (such as chemical composition, water activity, $\mathrm{pH}$, meat types and quantity, additives, microbial pollution), and so on. The effects of high pressure processing current research is not much, need a lot of researches for a long term.

\section{Principle of high pressure processing and high pressure process equipment}

Basic Governing Principles. As with heat, pressure is a basic thermodynamic variable. Strictly speaking, during HPP the effects of temperature cannot be separated from the effects of pressure. This is because for every temperature there is a corresponding pressure. Thermal effects during pressure treatment can cause volume and energy changes. However, pressure primarily affects the volume of the product being processed. The combined net effect during HPPmay be synergistic, antagonistic, or additive.

Mathematically, the impact of pressure $(p)$ and temperature $(T)$ can be quantitatively related using Gibbs's definition of free energy $G$ :

$$
G \equiv H-T S,
$$

where $H$ and $S$ are the enthalpy and entropy, respectively. Further,

$$
H \equiv U+p V,
$$

where $U=$ internal energy and $V=$ volume.

It can be deduced from Equations 1 and 2 that

$$
d(\Delta G)=\Delta V d p-\Delta S d T .
$$

Therefore, reactions such as phase transitions or molecular reorientation depend on both temperature and pressure and cannot be treated separately. Thefollowing are some basic governing principles behind HPP.

The fundamental principles of hyperbaric technique are pascaline law and Le Chatelier principle. Pascaline law takes advantage of the compression effect of high pressure on liquids, which means that the pressure applied to the liquid can be transmitted to all parts of 
the system instantaneously at the same size. Therefore, dry food, powdery food or granular food should not be used high pressure treatment. According to Pascaline law, the effect of high pressure processing is independent of the size, shape and volume of the food. In the process of high pressure processing, the whole food will be treated uniformly, the pressure transfer speed is fast, there is no pressure gradient. Therefore, the high pressure processing of food is simpler, and the energy consumption is also significantly reduced. According to Le Chatelier principle, the external pressure reduces the volume of the pressurized system and vice versa. Therefore, the physical and chemical reactions in food ingredients will be carried out in the direction of the maximum compression state under the pressure treatment of food. The increase or decrease of the reaction rate constant $k$ depends on whether the "active volume" of the reaction is positive or negative. This means that high pressure processed food will force the reaction system to reduce the volume, affecting not only the reaction balance in the food, but also the reaction rate, including chemical reactions and possible changes in molecular conformation. It is well known that the mechanism of meat proteins unfolded, denaturation and formed gel caused by heat and high pressure is difference. High pressure processing induced meat gels are based on the protein volume decline, while the thermal meat gels is caused by the violent movement of molecules and destruction of non-covalent bonds.

Principle of microscopic ordering. At constant temperature, an increase in pressure increases the degree of ordering of molecules of a given substance. Therefore, pressure and temperature exert antagonistic forces on molecular structure and chemical reactions.

Arrhenius relationship. As with thermal processing, various reaction rates during HPP are also influenced by thermal effects during pressure treatment. The net pressure-thermal effects can be synergistic, additive, or antagonistic.

High-pressure processing of muscle based products is paying more and more attention in the meat industry, which could prolong the shelf life of meat products, inactivate vegetative micro-organisms and enzymes near room temperature, because of the processing allows the decontamination of muscle based products with minimal i MPact on their nutritional and sensory features. Therefore, The application of high pressure offers some interesting opportunities in the processing of muscle-based food products, such as, the high pressure can affect the texture and gel-forming properties of meat batter and myofibrillar proteins, the tenderize, color and other properties of muscle. The processing effects on muscle based products are highly dependent on the primary effects of pressure, time and temperature on the relevant thermodynamic and transport properties of meat systems. However, the pressurelabile nature of some meat protein systems, such as myosin or myoglobin often limits the range of attractive commercial applications to prefermented and cooked meat products.

Pressure Generation Means. Unlike straight processes such as thermal processing, the high-pressure process is independent of the equipment and processed food size and shape. The reason is that the pressure transmission is not mass/time dependent. Hence, reducing the processing time and scaling up the equipment from the laboratory to commercial size will not touch the efficiency of HPP. In contrast, it helps the HPP applications to develop faster. Two types of the compression processes, direct (piston) or indirect (pump) compression can achieve generation of high pressures in the pressure vessels (Figure 1). 


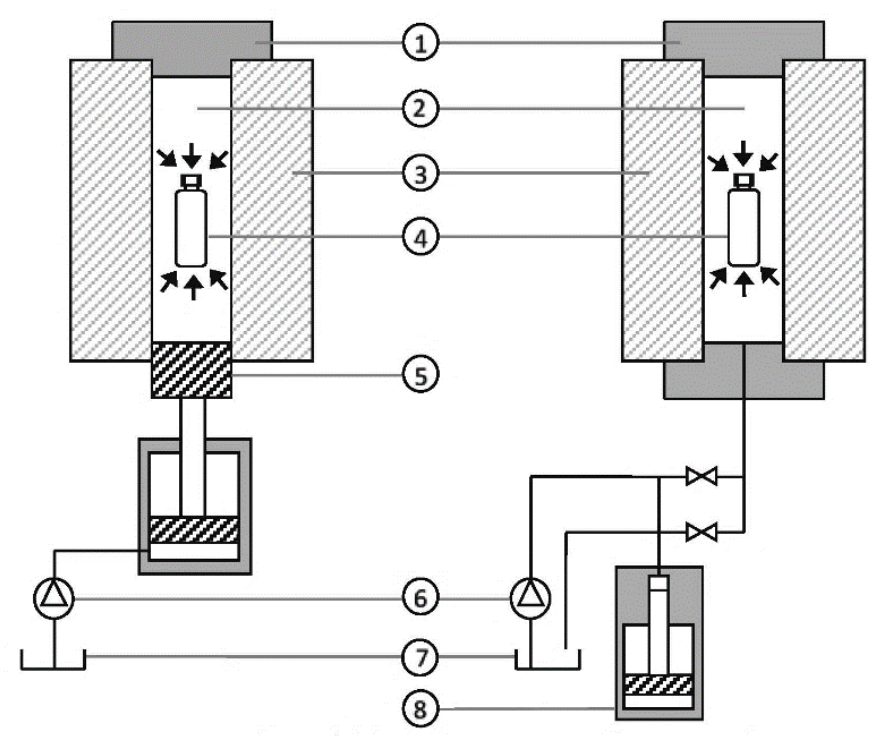

Figure 1. Schematics of high-pressure food processing techniques direct (left) and indirect (right) compression:

1 - Top closure; 2 - Pressure medium; 3 - Pressure vessel; 4 - Product; 5 - Piston; 6 - Low-pressure pump; 7 - Tank; 8 - Intensifier pump.

1. Direct compression. This technique uses the vessel ends closure/s to act as a piston to build/release the pressure. This happens by reducing the specific volume inside the vessel until the desired pressure is reached. Although, the direct system can achieve a rapid compression, the restrictions of the dynamic seal between the piston and the vessel obstruct the applications of this technique for a small-scale laboratory.

2. Indirect compression. Indirect compression is the method used in the application of much high pressure processing equipment in the food industry. It employs a high-pressure intensifier pump to compress a pressure fluid from its reservoir tank into a pressure vessel, transmitted through high-pressure tubes. This technique is more appropriate for solids and high viscous liquid food.

This method also allows pressure to be released or kept constant at the required level during the treatment time for several minutes.

\section{Effects of high pressure processing on the properties of muscle}

\subsection{Effects of high pressure processing on the $\mathrm{pH}$ of muscle}

The effects of high pressure processing on the $\mathrm{pH}$ of meat was depended on pressure levels, treatment time and temperature, meat temperature, muscle type and so on. The fresh meat had a rapid $\mathrm{pH}$ decrease and an intense contraction after high pressure treatment. The mainly reason is that pressurization induced contraction causing calcium release stimulating glycolysis, the changes of activity of phosphorylase, phosphorylase kinase and phosphorylase phosphatase, whose were breakdown the regulation of glycogen during the 
high pressure processing. The $\mathrm{pH}$ of red meat, such as ovine and bovine muscles were decreased $0.6-0.8$ unit after $100-150 \mathrm{MPa}, 1-5 \mathrm{~min}$ at $35^{\circ} \mathrm{C}$. However, the $\mathrm{pH}$ of withe meat, such as longissimus dorsi from rabbit had a larger decrease than the musseter after 10 min pressurisation (Cheftel, Culioli, 1997) [1]. The high pressure treatments also affected the ultimate $\mathrm{pH}$ of meat. The ultimate $\mathrm{pH}$ of pre-rigor pork longissimus increased by 0.48 after high pressure treatments at $215 \mathrm{MPa}$ [2] (Souza et al., 2011). Simonin et al. (2012) [3] showed that the HPP treatment of post-rigor muscles increased the ultimate $\mathrm{pH}$ of the meat [4]. MacFarlane (1973) found that the ultimate $\mathrm{pH}$ of muscle strips reduced from 5.31 to 5.26 with application of pressure up to $150 \mathrm{MPa}$. The differences were caused by the different meat type and pressure conditions.

The post-rigor meat had a slight $\mathrm{pH}$ increase after high pressure treatment, and the $\mathrm{pH}$ increased with the pressure levels increasing. The reason might be that the exposure of acidic groups were decrease due to conformational changes of proteins associated with denaturation during the high pressure processing [5] (Poulter et al. 2010). The $\mathrm{pH}$ of porcine and bovine M. semimembranosus muscles slightly increased from 5.6 to 5.8 after $400 \mathrm{MPa}, 20{ }^{\circ} \mathrm{C}, 10$ $\mathrm{min}$. The $\mathrm{pH}$ of the post-rigor bovine M. semitendinosus muscle slightly increased from 5.4 to 5.6 after high-pressure treatments at 100 and $400 \mathrm{MPa}, 15^{\circ} \mathrm{C}, 5 \mathrm{~min}$, respectively [6-7] (Kwiatkowska et al., 2002; Kim et al., 2007). Ma et al. (2019) [8] reported that the pH of yak meat (thigh muscle) increased with pressure levels increased from 0.1 MPa to $450 \mathrm{MPa}$. Morton et al. (2017) [9] found that the mean $\mathrm{pH}$ of the prime and bull were caused a significant increase, and the cow meat had a significant decrease after high-pressure treatments at $175 \mathrm{MPa}$, and the mean $\mathrm{pH}$ of meat from all the animal classes were significantly increased $(\mathrm{P}<0.05)$ by $250 \mathrm{MPa}$ treatment.

\subsection{Effects of high pressure processing on the color of muscle}

Meat color is one of the most important quality properties for the consumers in a purchase situation, which is determine to the consumers purchase it or not. For example, the consumers usually like a bright red color of beef meat, and a stable reddish/pink color of cured pork products, these were perceived as a sign of freshness (Schulte et al., 1995; Sikes Tume, 2014) [10,11].

Myoglobin is the most important meat pigment, making up 90-95\% of the total pigment content. Its concentration and chemical-physical state has a key step of the color of fresh and processed meat (Carlez, Veciana-Nogues, Cheftel, 1995) [12]. The color changes of meat induced by high pressure are basically dependent on three main mechanisms: 1) denaturation of myoglobin, 2) modification or disruption of the porphyrin ring, and 3) changes in the myoglobin redox chemistry (Bak et al., 2017) [13]. These were connection with the meat type, pressure conditions, $\mathrm{pH}$, and so on. High pressure conditions and myoglobin redox form prior to high pressure treatment are the main reasons for the color changes of pressurized meat. At low temperature, below $300 \mathrm{MPa}$ treatment have minor effects on color than the higher pressures. But the myoglobin is not stable, the denaturation had been found to take place at low pressures (Bak et al., 2012) [14]. Korzeniowski et al. (1999) [15] found that the $28 \%$ of myoglobin was denatured after $100 \mathrm{MPa}$ treatment, increasing to $66 \%$ denaturation of myoglobin after $400 \mathrm{MPa}$ treatment. Souza et al. (2011) [2] found that the high pressure treated longissimus dorsi, triceps brachii, and psoas major muscles had L* values that were 3.87, 6.37, and 2.71 units higher (lighter) $(\mathrm{P}<0.05)$ than controls. The $\mathrm{a}^{*}$ values for treated longissimus dorsi muscles were 0.94 units lower (less red) than controls, while treated triceps brachii muscles were 0.67 units higher (more red) than controls. Due to the denaturation of myoglobin, some researchers have reported that high pressure possible gives the fresh meat 
a cooked appearance which does not visually appeal to consumers. Carlez et al. (1995) [12] found that the color minced beef meat was changed into "whitening"when the pressures over $200 \mathrm{MPa}$, the main reason is that a whitening effect due to myoglobin denaturation and/or to haem displacement or release and oxidation of the ferrous myoglobin to ferric myoglobin above 400 MPa. Bolumar et al. (2012) [16] showed that the beef color changes caused by high pressure was similar in appearance to the color change upon cooking, such as lightness increased, redness decreased and yellowness remained more or less unchanged, although the color changes induced by cooking and high pressure have different mechanisms. The oxidation state of the iron in myoglobin is a key factor on the meat color treatment by high pressure. Due to the light reflection and scattering increased, $L^{*}$ value of pork increases at pressures up to $400 \mathrm{MPa}$. The other reason is possible that the myofibrillar proteins was decreased the solubility and formed of larger insoluble protein aggregates during the high pressure treatment, which may affect the meat surface and the light reflectance (Olsen and Orlien, 2016) [17]. Wackerbarth et al. (2009) [18] studied the effect of high pressure processing on structural changes of pork myoglobin by resonance Raman spectroscopy, found that the oxy-myoglobin was changed into the formation of met-myoglobin and further denatured ferric $\mathrm{Mb}$ species, the structural transition could cause a colour change and initiate unwanted oxidative side reactions involving further components of meat. High pressure treated meat samples have a high ultimate $\mathrm{pH}$, that led to their color became darker. Brewer et al. (2001) [19] reported that higher $\mathrm{pH}$ of high pressure treated is correlated with lower $\mathrm{L}^{*}$ values causing the meat to appear darker. The chicken meat has low content of myoglobin, is considered "white meat". Therefor, the color of raw breast is slightly pinkish, the appearance is bluish-white to yellow. Therefore, the effect of high pressure on color is not different from beef and pork meat. The lightness, redness and yellowness of whole chicken breast fillets were increased after 300-600 MPa treatment. The increase of redness was caused by the reversible renaturation of pressure-denatured myoglobin (Kruk et al., 2011; Del Olmo et al., 2010) [20-21]. Overall, high pressure treatment of meat has a great impact on meat color, generally, the lightness was increased and the red of pork and beef was decreased, which is an interrelationship the modifications of myoglobin molecules.

\subsection{Effects of high pressure processing on the water holding capacity of muscle}

The effects of high pressure processing on the water holding capacity of meat was depended on pressure levels, treatment time and temperature. Ma et al. (2019) [8] reported that with increased time and pressure, the water holding capacity of the yak meat increased first and then decreased. At $250 \mathrm{MPa}, 15 \mathrm{~min}$, the water holding capacity had a increase of $10.50 \%$ and the meat turned white.The reason is that high pressure processing caused by reduced exposure of acidic groups and increased the $\mathrm{pH}$ levels of meat, which could improve the water holding capacity. When the high pressure and time were exceed, the meat has an excessive contraction and the water holding capacity decreased [22] (Hong et al., 2005). Souza et al. (2011) [2] also reported that the cooking loss of pork was decreased by $17.35 \%$ after being exposed to $215 \mathrm{MPa}$ at $33^{\circ} \mathrm{C}$ for $15 \mathrm{~s}$. If the pressure lever is too high, the activity of calpain, such as desmin, is been inhibited by high pressure and prevents the degradation of cytoskeletal proteins, and reduces the water-holding capacity of muscle (Campus, 2010) [23]. The high pressure and heat combined could improve the water retention in muscle, depending on the process parameters. When pressure treatment at 100 to $200 \mathrm{MPa}$, the drip loss and free water of pork meat were increase from $4 \%$ to $7 \%$, and at 300-400 MPa these were decreased to $4 \%$. The cooking yield of pork meat by previously high-pressure-treated at 300 to $400 \mathrm{MPa}$ was significantly higher than that found for heated-only samples; they 
were no difference between heated-only samples and high-pressure-treated at 300 to $400 \mathrm{MPa}$ (Korzeniowski et al., 1999) [15]. These different results for water holding capacity were caused by the different temperatures and pressure levels. Some researches have reported the high pressure processing could use to improve the quality of heterogeneous meat. The pale, soft, and exudative (PSE) meat has lower muscle $\mathrm{pH}$ is associated with lower water holding capacity. The high pressure processing may improve the water holding capacity of PSE meat. Chan et al. (2011) [24] found that the expressible moisture of PSE-like turkey breast meat was decreased at 50 and $100 \mathrm{MPa}$, and the lowest level occurring at $100 \mathrm{MPa}(18.7 \%)$, the result in that the water holding capacity was increased at these pressure levels. However, the water holding capacity was decreased significantjy $(\mathrm{P}<0.05)$ at $150 \mathrm{MPa}$ for $5 \mathrm{~min}$ at $4^{\circ} \mathrm{C}$, because of the less hydrophobic interactions and lower protein surface hydrophobicity at 150 MPa. In addition, the effects of water characteristics in meat treated by high-pressure have been researched. Bertram (2004) [25] studied the effect of water characteristics in cooked beef by nuclear magnetic resonance, found that the $\mathrm{T} 2$ values were lower in pressure-heat treated meat revealing alterations in water characteristics of pressure-treated, cooked meat co MPared with cooked meat, and the shear force of pressure treated samples were lower. The high pressure treatment is affected the myofibrillar organization, which changes the properties of water in the meat and improved the tenderness of meat (Bertram, Purslow, Andersen, 2002) [26].

\subsection{Effects of high pressure processing on the tenderness of muscle}

Tenderness is identified as the primary eating quality factor, which is the key determinant of whether consumers are repeat buyers or not Miller, Carr, Ramsey, (Crockett, Hoover, 2001; Platter et al., 2003) [27,28].

The tenderness of meat are depend on the myofibrillar and connective tissue proteins. The mechanisms of meat tenderisation that occurs in high pressure processing of pre-rigor muscles and chill ageing of post-rigor muscles are differences. High pressure treatment could cause changes in the muscle microstructure, sarcomere contraction, muscle fiber damages, and myofibril fragmentation, such as hydrolyzed the proteins in the muscle fibers, weakened the cell structure, released the ions and activated calcium activating enzymes (Lowder et al., 2014) [29]. Calpains are a large family of cytoplasmic cysteine $\mathrm{Ca}^{2+}$ dependent proteases in skeletal muscle, some papers found they are contact with the post-mortem proteolysis and meat tenderization, which are able to degrade myofibrillar proteins including nebulin, titin, troponin-T and desmin (Hufflonergan et al., 1996; Kristensen Purslow, 2001) [30,31]. Homma et al. (1996) [32] found that the calpain activity of muscle was increased by pressure up to $200 \mathrm{MPa}$ caused by $\mathrm{Ca}^{+}$, which was released from the sarcoplasmic reticulum and to the inactivation of the inhibitor calpastatin during the pressure treatment. Morton et al., (2018) [33] reported that high pressure processing could direct physical disruption of the sarcomeres, destroyed the organised structure of the sarcomere $\mathrm{Z}$ discs, $\mathrm{M}$ lines and $\mathrm{A}$ bands. Bouton et al. (1977) [34] obtained that high pressure processing is a clean technology that can tenderise post-rigor meat with the appropriate pressure levels and temperatures. Souza et al. (2011) [2] found that the shear force of pork were decreased by 30\% after $215 \mathrm{MPa}$ for $15 \mathrm{~s}$ at $33{ }^{\circ} \mathrm{C}$. The similar results was reported that after $300 \mathrm{MPa}$ for $20 \mathrm{~min}$ at $20{ }^{\circ} \mathrm{C}$ treatment, the shear force of goose breast were decreased by $34.78 \%$ (Gao et al. 2014) [35].

The shear force of hot-boned beef was decreased after $175 \mathrm{MPa}$ treatment and improved the eating quality. Thus, the moderate pressure levels treatment of pre-rigor meat seems to have potential since the meat was tender and looked normal (Morton et al., 2017) [36]. Ma and Ledward (2013) [37] reported that the tenderness of pre-rigor meat after subjected to 
pressures of about 100-150 MPa was significantly improved co MPared to the untreated counterpart, and this method have become a commercially viable process, which given the decreasing cost of high pressure machines. Up to $60{ }^{\circ} \mathrm{C}$, the shear force of post-rigor meat was significantly reduced after subjected to pressures of 100-200 MPa. Some authors have reported that the post-rigour beef muscle treatments by high pressure had no beneficial effects, such as combined pressure-heating treatments, which result in brown discolouration (Ma Ledward, 2004; Ma et al., 2007) [38,39].

The connective tissue proteins is an important factor of the tenderization of meat, such as the state of linking myofibrils to the sarcolemma and other filaments from the cytoskeletal networ (Cheftel Culioli, 1997; Taylor et al., 1995) [1,40].

The thermal solubility of collagen was changed caused by $200-500 \mathrm{MPa}, 20^{\circ} \mathrm{C}, 10 \mathrm{~min}$, the thermal stability of thermally undenatured collagen was improved, and the thermal stability of partial collagen denaturation before pressurization might be reduced. Ichinoseki et al. (2007) [41] found that the thermal stability and surface hydrophobicity of beef collagen fibrils was decreased treatment by high pressure processing, caused the structural weakening of intramuscular connective tissue. The intramuscular connective tissue was benefit of improving the tenderness. Kim et al. (2007) [7] showed that the shear force of the bovine M. semitendinosus muscle was decreased significantly treated by $100-500 \mathrm{MPa}, 15^{\circ} \mathrm{C}, 5 \mathrm{~min}$, after cooking to an internal temperature of $75^{\circ} \mathrm{C}$.

\section{Effect of high pressure on the comminuted meat products}

For years, the demand of comminuted meat products is increasing, which have enjoy widely consumer acceptance in certain sections of the global population (Delgado-Pando et al., 2010; Kang et al., 2017) [42,43]. The tradition comminuted meat products contain higher salt and fat, overtake the salt and fat could increases the risk of obesity, hypertension and cardiovascular disease (Jeon et al., 2015; Yalcin Seker, 2016) [44,45]. However, the salt and fat content have a key factor in the solubilization of the myofibrillar proteins, as it is these proteins that determine the binding and textural characteristics of the product, they are also contributes to flavor of comminuted meat products (Pietrasik Li-Chan, 2002; Tobin, O'Sullivan, Hamill, Kerry, 2013; Kang et al., 2014) [46-48]. For declining the animal salt and fat content of emulsion meat products, high pressure processing has caught the interest of emulsion meat products because it meets consumer's requirements for low fat and salt content, which has been renewed as a best non-thermal intervention for extending the shelflife and safety of comminuted meat products without altering the sensory and nutritional properties (Hygreeva Pandey, 2016; Chen et al., 2018) [49,50].

\subsection{Effect of high pressure on the water and fat holding capacity of comminuted meat products}

The water and fat holding capacity expresses the ability of comminuted meat products to hold water and fat, which is an important indicator of products quality. In the gelation process proteins undergo unfolding and denaturation followed by protein association, forming a three dimensional network which entraps water molecules and thus produces a gel. The pressure intensity, salt content, meat type, composition, temperature and others factors independently affected both the water and fat holding capacity of comminuted meat products. Carballo et al. (2000) [51] found that the post-rigor pork gel structures had better water binding properties but were weaker than non-pressurized meat batters and batters pressurized prior to heating. Zheng et al. (2017) [52] reported that the cooking loss was not decrease 
caused by addition of salt with high pressure treated chicken meat batters, this suggested that high pressure was much more effective than salt in reducing water loss during the cooking. Rospolski et al. (2015) [53] studied the effects of high pressure processing parameters and $\mathrm{NaCl}$ concentration on the physical properties chicken meat batter, showed that water became slightly more tightly bound to the meat matrix after high pressure processing treatment, main reason is the high pressure processing could increase the solubility of muscle proteins, thus increasing water and fat holding capacity and decreasing mechanical water loss (Chan et al., 2011; Sikes, Tobin, Tume, 2009) [54,5 5]. Villamonte et al. (2013) [56] also observed an increase in water holding capacity due to the interaction of high pressure processing and salt in pork meat batter, this may be because increasing sodium chloride causes increasing denaturation of muscle proteins in high pressure treated meat batters and favors the solubilization of proteins and the formation of a gel network that retains water and fat.

The high pressure processing and heating $\left(>40{ }^{\circ} \mathrm{C}\right)$ combinations limits the gelling process of meat systems. The pork and chicken meat batters had better water binding properties after $200-400 \mathrm{MPa}$ treated for $30 \mathrm{~min}$, at $60-80{ }^{\circ} \mathrm{C}$, however, the gel structures were weaker than gels made by heating (non-pressurized) or pressurized prior to heating (Fernandez, 1998; Colmenero, 2002; Yang et al., 2015) [57-59]. Marcos et al. (2010) [60] also reported that the higher cooking yield was observed at $40{ }^{\circ} \mathrm{C}$ compared to $60{ }^{\circ} \mathrm{C}$ in ostrich meat sausage by pressurization before heating.

Under adequate conditions, application of high pressure treatment modifies the functionality of non-meat protein and polysaccharide molecules and significantly promotes the emulsifying activities and stability [61].

Moreover, some researches have reported a synergistic effect of dietary fibre, soy protein isolate, starch, hydrophilic colloid, and others material and high pressure processing on water and fat holding capacity in high pressure processing treated comminuted meat products. Grossi et al. (2011) [62] investigate the synergistic cooperation between high pressure treatment and carrot dietary fibre, found that high pressure treatment and carrot dietary fibre markedly improved emulsion strength resulting in firm pork sausages. Moller et al. (2011) [63] found that the significant effects of pressure temperature, holding time, and addition of carrot fibre on the distribution and mobility of water, and the $T_{2}$ relaxation times were able to explain more than $90 \%$ of the variation in water holding capacity for both nonpressure and pressure-treated sausages, combined high pressure treatment and addition of fibre caused non-coherent changes in $T_{2}$ NMR relaxation times. Chun et al. (2014) [64] used of the soy protein isolated, wheat flour (WF), and $\kappa$-carrageenan as binder, showed that the addition of binders improved water-binding properties of pressure or non-pressure-induced restructured pork, but lowered the hardness. Hong et al. (2004) [65] investigate the effect of high pressure and the addition of non-meat proteins on the physico-chemical and binding properties of restructured pork, found that high pressure and added isolated soy protein, sodium caseinate, whey protein concentrate and egg white powder improved the water binding capacities and binding strength of the restructured pork, respectively. However, due to the excessive protein damage reflected as increased surface hydrophobicity, less proteinwater interactions and thus lower water-binding properties of sodium caseinate and whey protein concentrate, added sodium caseinate and whey protein concentrate were no effect on water binding properties under high pressure. Thus, the application of high pressure had more significant effect on restructuring meat than binders (Uresti et al., 2004) [66].

The high pressure treated whey protein isolate showed a continuous fine stranded network, while egg albumen had a porous aggregated network. The heated mixtures of whey protein isolate:egg albumen (7.5:7.5) showed large dense aggregates whereas high pressure treated mixtures produced smaller aggregates (Ngarize, Adams Howell, 2005) [67]. 
Trespalacios and Pla (2009) [68] used the dried egg white as fat replacement to obtain a lowfat chicken gel by means of high pressure, the water binding properties and hardness were improved, suggested their participation in the network structure coupled to the myofibrillar proteins, and noted that the modifying certain functional characteristics of chicken meat gels with low fat content by means of high pressure and the addition of dried egg white.

\subsection{Effect of high pressure on the texture of comminuted meat products}

The texture of comminuted meat products is an important factor to determined the consumers purchased or not. The high pressure treatment was effected the hardness, springiness, adhesiveness, gumminess and chewiness of emulsion meat products. High pressure processing induced texture modifications have been used to affect myofibrillar proteins and their gel-forming properties, raising the possibility of the development of processed comminuted meat products. Over $200 \mathrm{MPa}$ treatment, the protein extractability was decreased significantly in meat batters, and caused protein denaturation and/or aggregation, which limited their functionalities (Oflynn et al., 2014; Sazonova et al., 2019) $[69,70]$.

The M-line and Z-line of the chicken myofibril in $0.2 \mathrm{M} \mathrm{NaCl}$ were disrupted, and the thin and thick filaments were dissociated by high pressure treatment. The microstructure of pressure-heat-induced chicken myofibrillar gel was composed of three-dimensional fine strands. Pressurization, at $200 \mathrm{MPa}$, prior to heating, increased the apparent elasticities of chicken myofibrillar gel; however, pressure treatment above $200 \mathrm{MPa}$ decreased it (Iwasaki, Noshiroya, Saitoh, Okano, Yamamoto, 2006) [71]. Yang et al. (2015) [52] have studied that the use of high pressure processing for enhancing the functional properties of reduced-fat (20\%) and reduced-salt (1\%) pork sausages without the need for additives, found that the textural properties of hardness, chewiness, springiness, cohesiveness and resilience were significantly $(\mathrm{P}<0.05)$ increased at an interval of $100 \mathrm{MPa}$ and $200 \mathrm{MPa}$, except the textural property of adhesiveness up to $200 \mathrm{MPa}$, but no changes of hardness, chewiness, springiness and resilience were observed up to $300 \mathrm{MPa}$ and $400 \mathrm{MPa}$. Hwang, Lai, and Hsu (2007) [72] shown that the sausages had a harder texture after $200 \mathrm{MPa}$ treatment, mainly because of partly depolymerized, unfolded, aggregated and denatured the extracted proteins under 200 $\mathrm{MPa}$, which caused the changes of water distributions, formed new protein components, and solubilization or denaturation of myofibrillar proteins [73].

Some researchers have study the use of high pressure treatment to reduce the salt or phosphate content of comminuted meat products. Oflynn et al. (2014) [74] found that high pressure treatment is a potential technology to manufacture sausages maintaining organoleptic and functional properties, and could decrease the salt levels in reducedphosphate breakfast sausages, improve the juiciness and cohesiveness.

Sikes et al. (2009) [48] reported that the myofibrillar proteins, such as myosin and actin, were more salt soluble when low-salt beef sausage batters were subjected to high pressure at $200 \mathrm{MPa}$ than the untreated batter.

Hygreeva et al. (2016) [75] study the effects on quality characteristics of precooked chicken patties were subjected to high pressure at 200, 400 and $600 \mathrm{MPa}$ for $10 \mathrm{~min}$, the result indicated that the textural properties of chicken patties were improved after treated at 200 and $400 \mathrm{MPa}$. Crehan et al. (2000) [76] found that the hardness, cohesiveness, gumminess and chewiness of frankfurters were improved after 150 and $300 \mathrm{MPa}$ treatment at low salt content $(1.5 \%)$. Therefore, the texture properties of comminuted meat products with low slat content could be improved at moderate pressure levels (100 300 MPa). 
The changes of texture properties also are related to the pressure temperature and processing, the possible is that the modified conformation, slowed heat-denaturation, together with disrupted myofibrillar eventually led to the different batter structures. The cooking of meat batters either before or after high-pressure treatment results in varying effects on meat product texture. Mor-Mur and Yuste (2003) [77] found that the textural properties of vacuum packed cooked sausages were treated at $500 \mathrm{MPa}$ and $65^{\circ} \mathrm{C}, 5$ or 15 min improved cohesiveness and increased fracture force of the product. Zheng et al. (2017) [52] studied the effect of heating under high pressure conditions $\left(0\right.$ to $400 \mathrm{MPa}, 75^{\circ} \mathrm{C}, 30$ $\mathrm{min}$ ) and sodium chloride ( 0 to $2.0 \mathrm{~g} / 100 \mathrm{~g}$ ) on the texture, the results showed that the physical properties of batters were subjected by high pressure depended on the pressure intensity. The chicken meat batters treated at $200 \mathrm{MPa}$ exhibited desirable qualities, having a smooth appearance and rigid texture, while those treated at $400 \mathrm{MPa}$ had undesirable qualities, being coarse and watery in appearance, with a weak texture. The structural changes induced in proteins of meat batters were partially reversible at low temperatures when Increasing the pressure from 100 to $300 \mathrm{MPa}$, however, these changes were irreversible when the pressures beyond $300 \mathrm{MPa}$ (Rastogi, Raghavarao, Balasubramaniam, Niranjan, Knorr, 2007) [78].

Carballo et al. (2000) [79] reported that the pork batters treated by high pressure prior to heating decreased the hardness, springiness and chewiness, formed a coarse, irregular, loose protein matrix and favoring weaker gel structures, because pressure could limit proteinprotein interaction (Carballo,FernaÂndez JimeÂnez-Colmenero, 1996) [51].

Some researchers had reported that high pressure induced muscle protein gels form a firmer texture. Yang et al. (2016) [80] reported that compared with the values of $0.1 \mathrm{MPa}$ treated sausages, the $200 \mathrm{MPa}$ for $2 \mathrm{~min}$ at $10^{\circ} \mathrm{C}$ were significant $(\mathrm{P}<0.05)$ increased in all the textural values. Zheng et al. (2015) [81] showed that high pressure treatment before heating sausages had significantly higher values for hardness, springiness, cohesiveness, chewiness and resilience than did the only-heat sausages.

It is well known, that high pressure causes protein denaturation with increasing the pressure and temperature (Tintchev et al., 2013; Rastogi et al., 2007) [78, 82]. The myosin protein have completely denaturation by $200 \mathrm{MPa}$, at $50{ }^{\circ} \mathrm{C}$ and $60{ }^{\circ} \mathrm{C}$, the reason is the pressure and heat combined could be improved the efficient of protein aggregation and gelation, and form a heat induced helix-coil transition (Buckow, Sikes Tume, 2013) [83]. Which indicated that excessive temperature resulted in the weakening of molecular interactions and the destruction of the network structure in gels (Colmenero, 2002) [84]. In addition, the temperature with high pressure treatment was affected the state of moisture in the pork batters, which in turn affected the texture of the gel (Cando et al., 2014) [85].

Other factors also affected of the texture properties, such as added non-meat proteins, hydrophilic colloid. Hong and others (2008) [86] have studied the effects of high pressure processing and $\kappa$-carrageenan on cold-set binding in restructured pork meat, found that the breaking force and tensile strength of restructured pork meat treated by $200 \mathrm{MPa}$ combined with $\kappa$-carrageenan were increased, and the pressure above $200 \mathrm{MPa}$ and addition of $1.5 \% \kappa$ carrageenan has potential use in cold-set meat restructuring.

Grossi et al. (2012) [87] reported that the use of carrot fibre and potato starch had more impact on textural properties in pork sausages with low salt content (1.2\%) treated by high pressure processing, and water binding capacity of low salt pork sausages was improved, which produced sausages with better sensory properties.

Lee et al. (2018) [88] also the use of sea tangle powder and high pressure treatment combinations to reduce the phosphate in emulsion-type sausage, the result indicated that due to the $\mathrm{pH}$ and protein solubility were increased after was subjected to high pressure treatment, the water holding capacity and instrumental hardness of sausages treated with a combination 
of sea tangle powder and high pressure treatment were similar as the sausages with $0.2 \%$ sodium pyrophosphate, and greater inhibition ability against lipid oxidation and bacterial growth.

\section{Effect of high pressure on the gel properties and protein conformation of myofibrillar proteins}

Myofibrillar proteins accounts for $50 \%$ 55\% of the total protein content in muscle, mainly composed of myosin and actin. Myofibrillar proteins are salt-soluble proteins, which are soluble in high ionic strength solution $(>0.3 \mathrm{M})$, it is decide to the gel properties, such as water holding capacity, texture, shelf life, and so on [89]. During the gel form, the helix-coil transitions of myosin tails and subsequent aggregation of myosin heads through intra- and intermolecular interaction, and then a three dimensional and crosslinked network is formed after partial unfolding or denaturation of myofibrillar proteins [90]. There is no doubt that high pressure induces certain alterations in myofibrillar proteins which influence their functional properties [91]. Myofibrillar proteins is sensitive to high pressure. The high pressure treatment is able to variable alterations on protein conformational structures, the quaternary structure of dissociates at $100 \sim 200 \mathrm{MPa}$, the tertiary structure is significantly affected above $200 \mathrm{MPa}$, and secondary structure changes take place at 300 700 MPa, which could improve the gelation properties of myofibrillar proteins [92,93].

\subsection{Effect of high pressure on the water holding capacity of myofibrillar proteins}

The water holding capacity of myofibrillar proteins gel was affected of the level, time and temperature of high pressure. When the pressure levels was low $(\leq 200 \mathrm{MPa})$, which could improve the solubility of myofibrillar proteins; over $300 \mathrm{MPa}$, which could reduced solubility of myofibrillar proteins and form the large aggregates [24,94] observed that the denaturation of myosin of bovine occurred owing to the release of myosin light chain at 200 $\mathrm{MPa}$, and the rate of myosin denaturation increased rapidly at pressures above $300 \mathrm{MPa}$ because of the aggregation of myosin heavy chain. Actin were released at $200 \mathrm{MPa}$ and the denaturation of actin might have been accelerated by the aggregation of released actin at pressures above $300 \mathrm{MPa}$. The solubilization of myofibrillar proteins also was affected by temperature during high pressure processing. The solubilization of myofibrillar proteins increased with increasing temperature, especially from $40{ }^{\circ} \mathrm{C}$ to $60^{\circ} \mathrm{C}$, and a regular trend of protein solubilization was found when isolated myofibrils were subjected to high pressure at different temperatures, an increase was observed with increasing pressure up to about 400 $\mathrm{MPa}$, solubility then decreasing to $600 \mathrm{MPa}$ [95]. Barriosperalta et al. (2012) [96] found that myofibrillar proteins from abalone and starch interaction increases the emulsifying capacity at pressures over $350 \mathrm{MPa}$ applied for 3 5 min, myofibrillar proteins and egg white interactions at pressures higher than $450 \mathrm{MPa}$ for 5 10 min formed coagulation, decreasing the emulsifying capacity. The reason is that myosin of pressure-induced surimi gelation denaturation and concomitant disulfide bond formation at $300 \mathrm{MPa}, 5^{\circ} \mathrm{C}$ for $30 \mathrm{~min}$. During heating the pork myofibrillar proteins, aggregation of meat proteins caused the meat protein matrix to shrink, which reduced the amount of water that could be bound by the matrix, causing the cooking loss to increase [97]. Yang et al. (2015) [98] found that high pressure processing (200 MPa for $2 \mathrm{~min}$ ) significantly decreased $(\mathrm{P}<0.05)$ the cooked loss of reducedfat and reduced-salt pork sausages, and changed the P2 peak ratio of the four water components in raw pork sausages. Therefore, the high pressure has an important commercial and health benefit of the altered properties of myofibrillar proteins, which is their ability to 
form gels that have very high cook yields even in the presence of low salt [48]. Zhang et al. (2015) [99] showed that the myofibrillar proteins of chicken breast meat were treated at 100, $200,300,400,500 \mathrm{MPa}$ and kept for $10 \mathrm{~min}$, the centrifugation loss increased gradually from $36.59 \%(0.1 \mathrm{MPa})$ to $37.28 \%(200 \mathrm{MPa})$ and decreased sharply from to $30.82 \%(300 \mathrm{MPa})$ as the pressure increased from $200 \mathrm{MPa}$ to $300 \mathrm{MPa}$, then decreased slowly to $30.12 \%$ (500 $\mathrm{MPa}$ ); the relaxation time of $\mathrm{T}_{2 \mathrm{~b}}$ decreased from $2.31 \mathrm{~ms}$ to $1.32 \mathrm{~ms}, \mathrm{~T}_{21}$ had no significant changes, and $\mathrm{T}_{22}$ increased from $2477.08 \mathrm{~ms}$ to $3274.55 \mathrm{~ms}$, that means bound water had lower water mobility, immobilized water had no significant changes and free water had a higher water mobility.

\subsection{Effect of high pressure on the texture of myofibrillar proteins}

The texture is an important characteristic of myofibrillar proteins gel, which decides the quality of meat product. The solubility of myofibrillar proteins affects the texture of myofibrillar proteins gel, because of the functional properties of myofibrillar proteins requires the solubilization of the proteins. High pressure is an important thermodynamic parameter that can profoundly influence molecular systems. The high pressure treatment could induce the depolymerisation of myofibrillar proteins with a consequence of increasing solubility. Iwasaki et al. (2006) [100] found that the elasticity of chicken myofibrillar gels were apparent increased by 2 - or 3-fold at $200 \mathrm{MPa}(10-20 \mathrm{~min})$, prior to heating at $70{ }^{\circ} \mathrm{C}$. Cando et al. (2015) [101] showed that the surimi gel had higher breaking force after $150 \mathrm{MPa}$ treatment, but decreased the breaking force after $300 \mathrm{MPa}$ treatment. It is well known that high pressure processingis an important thermodynamic parameter that can profoundly influence molecular systems. When the high pressure over $400 \mathrm{MPa}$ can readily denature proteins, and $200 \mathrm{MPa}$ only affects their quaternary structures, leading to the dissociation of oligomeric proteins [102]. Zhang et al. (2017) [92] reported that the gel hardness of myofibrillar proteins increased from $20.25(0.1 \mathrm{MPa})$ to $46.6 \mathrm{~g}(200 \mathrm{MPa})$, then decreased gradually to $33.3 \mathrm{~g}(500 \mathrm{MPa})$. The main reason is the high pressure treatment could affect molecular interactions (hydrogen bonds, hydrophobic interactions and electrostatic bonds) and protein conformations, which lead to denaturation, dissociation, aggregation of myofibrillar proteins, then resulting in modified functional properties [103]. Angsupanich, et al. (1999) [104] found when isolated myofibrillar protein from turkey was pressure treated at $200 \mathrm{MPa}$, there was no change in any of the peaks of DSC, up to $400 \mathrm{MPa}$ and above caused loss of the myosin peak andmajor loss of actin structure and a 'new' peak (peak $\mathrm{N} \approx 53-54$ ${ }^{\circ} \mathrm{C}$ ). Ko et al. (2003) [105] reported that the increase of the surface hydrophobicity of myosin with the improving the pressure levels, which caused the structural changes of myosin, would compensate for the decrease in the gel strength of myosin, this would cause the decreases in $\mathrm{G}^{\prime}$ values.

Textural properties of protein gel greatly depended on its microstructure. Ma, et al. (2011) [95] reported that myosin light chains and actin thin filaments of beef muscle were sensitive to pressure, they were released from myofibrils subjected to $100 \mathrm{MPa}$. Suzuki et al. (1991) [106] found that the proteins of actin, tropomyosin, troponin C as well as M-protein were solubilized at $100 \mathrm{MPa}$, whereas solubilization of myosin heavy chains over $300 \mathrm{MPa}$. Therefore, the muscle type, $\mathrm{pH}$, temperature, and salt type and concentration were effected the solubility and texture the during the high pressure treatment. Cao et al. (2012) [107] observed by scanning electron microscopy that the network structure of rabbit myosin thermally induced gel was small and uniform after $200 \mathrm{MPa}$ treatment, while the gel holes became larger above $200 \mathrm{MPa}$, and the $\mathrm{G}^{\prime}$ and $\mathrm{G}^{\prime \prime}$ values were decreased with the pressure levels increased. Zhang et al. (2017) [92] found that due to the myofibrillar proteins were 


\section{- Food Technology}

partial unfolded, the gels contained many filaments and irregular cavities at $100 \mathrm{MPa}$; the smallest particle size of myofibrillar proteins was formed at $200 \mathrm{MPa}$, the gels had denser and homogeneous network, and the hardness had a largest value; the myofibrillar proteins denatured excessively, interior hydrophobic and sulfhydryl groups exposed above $300 \mathrm{MPa}$, the gel cavities became larger and heterogeneous, and the hardness was decreased. Overall, myofibrillar proteins gels with higher hardness had smaller, denser and homogeneous gel microstructure, while gels with lower harness had larger cavities and coarse microstructure.

\subsection{Effect of high pressure on the non-covalent bond, covalent bond and protein conformation of myofibrillar proteins}

High pressure processing can affect myofibrillar proteins molecular interactions (hydrogen bonds, hydrophobic interactions, sulfydryl and electrostatic bonds) and protein conformation (secondary and tertiary structures), leading to protein denaturation, aggregation, or gelation that presents altered functional properties $[108,109]$. Which could be to improve the gel-forming properties of muscle proteins, a crucial factor in processed muscle-based food. The pressure-induced aggregation involved the dissociation of myosin heavy and light chains followed by aggregation of the heavy chains [110]. The proteins from the thin filament such as actin, tropomyosin, troponin $\mathrm{C}$ as well as M-protein were solubilized at $100 \mathrm{MPa}$, and myosin light chains also was sensitive to pressure, and were released from myofibrils subjected to $100 \mathrm{MPa}$, whereas solubilization of myosin heavy chains required up to $300 \mathrm{MPa}[95,106]$. Some authors had reported that the high pressure processing affects chemical forces of myofibrillar proteins $[24,99,108]$. Due to more tryptophan hydrophobic residues and phenolic hydroxyl groups of tyrosine residues tended to be buried in a hydrophobic microenvironment and generated hydrogen bonds with protein molecules, the hydrogen bonds appeared to be strengthened under pressure [1,99]. The intermolecular $\mathrm{H}$ bonds between proteins was formed and caused the aggregation, which could decreased the solubility of myofibrillar proteins when the pressure up to $400 \mathrm{MPa}$ and above, due to the protein-protein interaction at pressure $400 \mathrm{MPa}$ is formed at the expense of protein-water interactions, and the intermolecular $\mathrm{H}$-bonds between proteins are stronger than the $\mathrm{H}$-bonds between protein and water [103]. Angsupanich, et al. (1999) [104] studied the effect of isolated myofibrillar protein and myosin of cod or turkey $(\mathrm{pH} \approx 7)$ were subjected to pressures up to $800 \mathrm{MPa}$ for $20 \mathrm{~min}$, found that high pressure-induced denaturation of myosin led to the formation of structures that contained hydrogen bonds and were additionally stabilized by disulfide bonds. It is well hnown that the breakdown of a disulphide bond requires an energy of $213.1 \mathrm{~kJ} / \mathrm{mol}$, but the high pressure treatment at $10,000 \mathrm{MPa}$ only provides only $8.37 \mathrm{~kJ} / \mathrm{mol}$. Thus, the increase of the reactive sulphydryl groups content might cause by a change of myosin structure involving the active sites of myosin, which could lead to changes in actomyosin formation and enzymatic properties of myosin. The surface hydrophobicity was significantly positive with pressure level.

The myofibrillar proteins protein became more unfolded with the pressure increased, more buried hydrophobic residues were exposure, and more hydrophobic sites or pockets of protein molecules could bind to the ANS (1-anilinonaphthalene-8-sulphonic acid), then large protein aggregates was formed. Zhang et al. (2015) [99] found the surface hydrophobicity of myofibrillar proteins from chicken breast meat increased slowly from $0.1 \mathrm{MPa}$ to $100 \mathrm{MPa}$, and then a sharp increase when treated by high pressure above $200 \mathrm{MPa}$. Cao et al. (2012) [107] showed that a clear positive relationship between pressure level applied and hydrophobicity, and increased significantly $(\mathrm{P}<0.05)$ above $200 \mathrm{MPa}$, that means an increased denaturation and unfolding of myosin and greater exposure of amino acid residues 
with increased pressure. Chapleau and de Lamballerie-Anton (2003) [111] studied the effect of pressure (0-600 MPa) and time (0-1,800 s) on the surface hydrophobicity, and reactive sulphydryl groups content of bovine myofibrillar proteins in solution at $10 \mathrm{~g} / \mathrm{L}$, the results found that high pressure treatment induced a threefold increase of the surface hydrophobicity of myofibrillar proteins between $0 \mathrm{MPa}$ and $450 \mathrm{MPa}$. The same upward trend was obtained on the reactive sulphydryl groups, which increased from $40 \%$ to $69 \%$. The increasing linked with the change of the secondary structure and the destruction of the $\alpha$-helices present in the heavy chains of myosin. Due to 100 or $200 \mathrm{MPa}$ is too low to affect the exposure of buried sulfhydryl groups, the SH content of myosin was not significantly differences $(\mathrm{P}>0.05)$, at $300 \mathrm{MPa}$ and above, the SH content was significantly increased $(\mathrm{P}<0.05)$, the increase of sulfhydryl groups might be explained by the change of myosin structure[107, 112].

The secondary structures of meat protein is sensitive to changes in the hydrogen bonding scheme involving the peptide linkages of amide I band, which is attributable to $\alpha$ helice, $\beta$-sheet, $\beta$-turn and random coil structures, respectively. Berhe et al. (2014) [113] had reported that the meat protein cooked above $60{ }^{\circ} \mathrm{C}$ were positively correlated to the high intensity of bands at the amide I regions. The results indicated that it was a significant $(\mathrm{P}<$ 0.05 ) increase in the $\beta$-sheet and $\beta$-turn structure content acco MPanied by a concomitant decrease in $\alpha$-helice content. Zhang et al. (2017) [92] found that increased the pressure levels, $\alpha$-helix and $\beta$-sheet changed into random coil and $\beta$-turn, and the surface hydrophobicity and formation of disulfide bonds were strengthened. Co MPared with the only-heat, when high pressure at $200 \mathrm{MPa}, 15 \mathrm{~min}$, the contents of $\beta$-sheet and $\beta$-turn were a significant increase $(\mathrm{P}<0.05)$ from $20^{\circ} \mathrm{C}$ to $40{ }^{\circ} \mathrm{C}$, and there were no significant different $(\mathrm{P}>0.05)$ from $50{ }^{\circ} \mathrm{C}$ to $60{ }^{\circ} \mathrm{C}$, because of the myofibrillar protein had completely denaturation.

The high pressure treatment was significantly effect of the gel properties and protein conformation of myofibrillar proteins gel. The high pressure treatment could provide great potential for myofibrillar proteins structural modification, such as lead to protein denaturation, solubilization, aggregation or gelation, thereby creating innovative functional properties. A moderate pressure ( $<200 \mathrm{MPa})$ can enhance water holding capacity and texture of myofibrillar proteins gel.

\section{Conclusion}

It is well established that high pressure processing will improved the properties of muscle, comminuted meat and myofibrillar proteins. The use of moderate pressure treatment of prerigor meat seems to have potential since the meat will be tender and look normal color. Reasonable high pressure processing could enhance the water holding capacity and texture of comminuted meat, but the products lacked the cooked appearance and potential for accelerated loss of flavour. Which also affected the non-covalent bond, covalent bond and protein conformation of myofibrillar proteins, the water holding capacity and texture of myofibrillar proteins will be increased produced by moderate pressure treatment. However, the affecting factors on properties of muscle, comminuted meat and myofibrillar proteins by high pressure processing is complex, still need a lot of research in the future.

Acknowledgments. This study was supported by National Natural Science Foundation of China (NSFC, grant no. 31571912). 


\section{References}

1. Cheftel J. C., Culioli J. (1997), Effects of high pressure on meat: A review, Meat Science, 46(3), pp. 211-236.

2. Souza C. M., Boler D. D., Clark D. L., Kutzler L. W., Holmer S. F., Summerfield J. W., Killefer J. (2011), The effects of high pressure processing on pork quality, palatability, and further processed products, Meat Science, 87(4), pp. 419-427.

3. Simonin H., Duranton F., de Lamballerie M. (2012). New insights into the high pressure processing of meat and meat products, Comprehensive Reviews in Food Science and Food Safety, Vol. 11, pp. 285-306.

4. Macfarlane J. J., McKenzie I. J., Turner R. H. (1982), Pressure-induced pH and length changes in muscle, Meat Science, 7(3), pp. 169-181.

5. Poulter R. G., Ledward D. A., Godber S., Hall G., Rowlands B. (2010), Heat stability of fish muscle proteins, International Journal of Food Science Technology, 20(2), pp. 203-217.

6. Kwiatkowska A., Jankowska B. and Cierach M. (2002), Changes in meat hydration upon high pressure, Polish Journal of Food Nutrition Science, 11, 52, pp. 51-54.

7. Kim Y., Lee E., Lee N., Kim Y. H., Yamamoto K. (2007), Effects of Hydrostatic Pressure Treatment on the Physicochemical, Morphological, and Textural Properties of Bovine Semitendinosus Muscle, Food Science and Biotechnology, 16(1), pp. 49-54.

8. Ma Y., Yuan Y., Bi X., Zhang L., Xing Y., Che Z. (2019), Tenderization of Yak Meat by the Combination of Papain and High-Pressure Processing Treatments, Food and Bioprocess Technology, pp. pp. 1-13.

9. Morton J. D., Pearson R. G., Lee H. Y., Smithson S., Mason S. L., Bickerstaffe R. (2017), High pressure processing improves the tenderness and quality of hot-boned beef, Meat Science, 133, pp. 69-74.

10. Schulte A., Buchter S., Galkin O., Williams C. (1995), Raman spectroscopic observation of a conformational change at the heme-protein linkage in myoglobin at high pressure, Journal of the American Chemical Society, 117(40), pp. 10149-10150.

11. Sikes A. L., Tume R. K. (2014), Effect of processing temperature on tenderness, colour and yield of beef steaks subjected to high-hydrostatic pressure, Meat Science, 97(2), pp. 244-248.

12. Carlez A., Veciananogues T., Cheftel J. C. (1995), Changes in Colour and Myoglobin of Minced Beef Meat Due to High Pressure Processing, LWT-Food Science and Technology, 28(5), pp. 528-538.

13. Bak K. H., Bolumar T., Karlsson A., Lindahl G., Orlien, V. (2017), Effect of high pressure treatment on the color of fresh and processed meats: A review, Critical Reviews in Food Science and Nutrition, pp. 1-25.

14. Bak K. H., Lindahl G., Karlsson A., Orlien V. (2012), Effect of high pressure, temperature, and storage on the color of porcine longissimus dorsi, Meat Science, 92(4), pp. 374-381.

15. Korzeniowski W., Jankowska B., Kwiatkowska A. (1999), The effect of high pressure on some technological properties of pork, Electronic Journal of Polish Agricultural Universities. Series Food Science and Technology, 02(2), pp. 1-8.

16. Bolumar T., Skibsted L. H., Orlien V. (2012), Kinetics of the formation of radicals in meat during high pressure processing. Food Chemistry, 134(4), pp. 2114-2120.

17. Olsen K., Orlien V. (2016), High pressure processing for modification of food biopolymers. In: Innovative Food Processing Techniques, pp. 291-313. Knoerzer K., Juliano P., and Smithers G. eds., Woodhead Publishing Limited, Cambridge.

18. Wackerbarth H., Kuhlmann U., Tintchev F., Heinz V., Hildebrandt P. (2009), Structural changes of myoglobin in pressure-treated pork meat probed by resonance Raman spectroscopy, Food Chemistry, 115(4), pp. 1194-1198.

19. Brewer M. S., Zhu L. G., Bidner B., Meisinger D. J., McKeith F. K. (2001), Measuring pork color: Effects of bloom time, muscle, $\mathrm{pH}$ and relationship to instrumental parameters, Meat Science, 57(2), pp. 169-176.

20. Kruk Z. A., Yun H., Rutley D. L., Lee E. J., Kim Y. J., and Jo C. (2011), The effect of high pressure on microbial population, meat quality and sensory characteristics of chicken breast 


\section{- Food Technology -}

fillet, Food Control, 22, pp. 6-12.

21. Olmo A. D., Morales P., Avila M., Calzada J., Nunez M. (2010), Effect of single-cycle and multiple-cycle high-pressure treatments on the colour and texture of chicken breast fillets, Innovative Food Science and Emerging Technologies, 11(3), pp. 441-444.

22. Hong G. P., Park S. H., Kim J. Y., Lee S. K., Min S. G. (2005), Effects of time-dependent high pressure treatment on physicochemical properties of pork, Food Science Biotechnology, 14(6), pp. 808-812.

23. Campus M. (2010), High Pressure Processing of Meat, Meat Products and Seafood, Food Engineering Reviews, 2(4), pp. 256-273.

24. Chan J. T., Omana D. A., Betti M. (2011), Application of high pressure processing to improve the functional properties of pale, soft, and exudative (PSE)-like turkey meat, Innovative Food Science and Emerging Technologies, 12(3), pp. 216-225.

25. Bertram H. C., Whittaker A. K., Shorthose W. R., Andersen H. J., Karlsson A. (2004), Water characteristics in cooked beef as influenced by ageing and high-pressure treatment - an NMR micro imaging study, Meat Science, 66(2), pp. 301-306.

26. Bertram H. C, Purslow P. P., Andersen H. J. (2002), Relationship between meat structure, water mobility and distribution - a low field NMR study, Journal of Agricultural and Food Chemistry, 50, pp. 824-829.

27. Miller M. F., Carr M. A., Ramsey C. B., Crockett K. L., Hoover L. (2001), Consumer thresholds for establishing the value of beef tenderness, Journal of Animal Science, 79(12), pp. 3062-3068.

28. Platter W. J., Tatum J. D., Belk K. E., Chapman P. L., Scanga J. A., Smith G. C. (2003), Relationships of consumer sensory ratings, marbling score, and shear force value to consumer acceptance of beef strip loin steaks, Journal of Animal Science, 81(11), pp. 2741-2750.

29. Lowder A. C., Waite-Cusic J. G., Mireles DeWitt C. A. (2014), High pressure-low temperature processing of beef: effects on survival of internalized E. coli O157:H7 and quality characteristics, Innovative Food Science Emerging Technologies, 26, pp. 18-25.

30. Hufflonergan E. J., Mitsuhashi T., Beekman D. D., Parrish F. C., Olson D. G., Robson R. M. (1996), Proteolysis of specific muscle structural proteins by mu-calpain at low $\mathrm{pH}$ and temperature is similar to degradation in postmortem bovine muscle, Journal of Animal Science, 74(5), pp. 993-1008.

31. Kristensen L., Purslow P. P. (2001), The effect of ageing on the water-holding capacity of pork : role of cytoskeletal proteins, Meat Science, 58(1), pp. 17-23.

32. Homma N., Ikeuchi Y., Suzuki A., Hayashi R., Balny C. (1996), Effect of high pressure treatment on proteolytic system in meat. In: Hayashi R, Balny C, editors. Progress in Biotechnololgy volume 13: high pressure bioscience and biotechnology. Proceedings of the International Conference on High Pressure Bioscience and Biotechnology, Kyoto, Japan: Elsevier pp 327-30.

33. Morton J. D., Lee H. Y., Pearson R. G., Bickerstaffe R. (2018). The physical and biochemical effects of pre-rigor high pressure processing of beef, Meat Science, 143, 129-136.

34. Bouton P. E., Harris P. V., MacFarlane J. J., O’Shea J. M. (1977), Effect of pressure treatments on the mechanical properties of pre- and post-rigor meat, Meat Science, 1(4), pp. 307-318.

35. Gao H., Zeng,J., Ma H., Wang Z., Pan R. (2014), Improving tenderness of goose breast by ultrahigh pressure, International Journal of Food Properties, 18(8), pp. 1693-1701.

36. Morton J. D., Pearson R. G., Lee H. Y., Smithson S., Mason S. L., Bickerstaffe, R. (2017), High pressure processing improves the tenderness and quality of hot-boned beef. Meat Science, 133, pp. 69-74.

37. Ma H., Ledward, D. A. (2013), High pressure processing of fresh meat - is it worth it?, Meat Science, 95(4), pp. 897-903.

38. Ma H. J., Ledward D. A. (2004), High pressure/thermal treatment effects on the texture of beef muscle, Meat Science, 68(3), pp. 347-355.

39. Ma H. J., Ledward D. A., Zamri A. I., Frazier R. A., Zhou G. H. (2007), Effects of high pressure thermal treatment on lipid oxidation in beef and chicken muscle, Food Chemistry, 104(4), pp. $1575-1579$.

40. Taylor R. G., Geesink G. H., Thompson V. F., Koohmaraie M., Goll D. E. (1995), Is Z-disk 
degradation responsible for postmortem tenderization?, Journal of Animal Science, 73(5), pp. 1351-1367.

41. Ichinoseki S., Nishiumi,T. and Suzuki A. (2007). Effect of high hydrostatic pressure on collagen fibril formation. Proceedings of 4th International Conference on High Pressure Bioscience and Biotechnology, Tsukuba, Japan, J-Stage, pp. 225-231.

42. Kang Z. L., Zhu D., Bin L. I., Hanjun M. A., Song Z. (2017), Effect of pre-emulsified sesame oil on physical-chemical and rheological properties of pork batters, Food Science and Technology International, 37(4), pp. 620-626.

43. Yalcin M. Y., Seker M. (2016), Effect of salt and moisture content reduction on physical and microbiological properties of salted, pressed and freeze dried Turkey meat. LebensmittelWissenschaft und -Technologie, Food Science and Technology, 68, pp. 153-159.

44. Delgado-Pando G., Cofrades S., Ruiz-Capillas C., Solas M. T., Jimenez-Colmenero F. (2010), Healthier lipid combination oil-inwater emulsions prepared with various protein systems: an approach for the development of functional meat products, European Journal of Lipid Science and Technology, 112(7), pp. 791-801.

45. Jeon H., Lee S. C., Cho Y. J., Oh J. H., Kwon K., Kim H. (2015), A triple-isotope approach for discriminating the geographic origin of Asian sesame oils, Food Chemistry, 167, pp. 363-369.

46. Kang Z., Zou Y., Xu X., Zhu C., Wang P., Zhou G. (2014), Effect of a beating process, as a means of reducing salt content in Chinese-style meatballs (kung-wan): a physico-chemical and textural study, Meat Science, 96(1), pp. 147-152.

47. Pietrasik Z., Li-Chan E. C. Y. (2002), Response surface methodology study on the effects of salt, microbial transglutaminase and heating temperature on pork batter gel properties, Food Research International, 35, pp. 387-396.

48. Tobin B. D., O'Sullivan M. G., Hamill R. M., Kerry J. P. (2013). The i MPact of salt and fat level variation on the physiochemical properties and sensory quality of pork breakfast sausages, Meat Science, 93, pp. 145-152.

49. Hygreeva D., Pandey M. C. (2016), Novel approaches in improving the quality and safety aspects of processed meat products through high pressure processing technology - A review, Trends in Food Science and Technology, 54(54), pp. 175-185.

50. Chen X., Tume R. K., Xiong Y. L., Xu X., Zhou G., Chen C., Nishiumi T. (2018), Structural modification of myofibrillar proteins by high-pressure processing for functionally improved, value-added, and healthy muscle gelled foods, Critical Reviews in Food Science and Nutrition, 58(17), pp. 2981-3003.

51. Carballo J. L., Cofrades S., Solas M. T., Jimenezcolmenero F. (2000), High pressure/thermal treatment of meat batters prepared from freeze-thawed pork, Meat Science, 54(4), pp. 357-364.

52. Zheng H., Han M., Yang H., Tang C., Xu X., Zhou G. (2017), Application of high pressure to chicken meat batters during heating modifies physicochemical properties, enabling salt reduction for high-quality products, LWT-Food Science and Technology, 84, pp. 693-700.

53. Rospolski,V., Koutchma T., Xue J., Defelice C., Balamurugan S. (2015), Effects of high hydrostatic pressure processing parameters and $\mathrm{NaCl}$ concentration on the physical properties, texture and quality of white chicken meat, Innovative Food Science and Emerging Technologies, 30, pp. pp. 31-42.

54. Chan J. T. Y., Omana D. A., Betti M. (2011), Effect of ultimate $\mathrm{pH}$ and freezing on the biochemical properties of proteins in turkey breast meat, Food Chemistry, 127, pp. 109-117.

55. Sikes A. L., Tobin A. B., Tume R. K. (2009), Use of high pressure to reduce cook loss and improve texture of low-salt beef sausage batters, Innovative Food Science Emerging Technologies, 10, pp. 405-412.

56. Villamonte G., Simonin H., Duranton F., Chéret R., de Lamballerie M. (2013), Functionality of pork meat proteins: I MPact of sodium chloride and phosphates under high-pressure processing, Innovative Food Science Emerging Technologies, 18, pp. 15-23.

57. Colmenero F. J. (2002), Muscle protein gelation by combined use of high pressure/temperature. Trends in Food Science and Technology, 13(1), pp. 22-30.

58. Jimenezcolmenero F., Cofrades S., Carballo J. L., Fernandez P., Fernandezmartin F. (1998), Heating of Chicken and Pork Meat Batters under Pressure Conditions: Protein Interactions, 


\section{— Food Technology -}

Journal of Agricultural and Food Chemistry, 46(11), pp. 4706-4711.

59. Yang H., Han M., Bai Y., Han Y., Xu X., Zhou G. (2015), High pressure processing alters water distribution enabling the production of reduced-fat and reduced-salt pork sausages, Meat Science, 102, pp. 69-78.

60. Marcos B., Kerry J. P., Mullen A. M. (2010), High pressure induced changes on sarcoplasmic protein fraction and quality indicators, Meat Science, 85(1), pp. 115-120.

61. Gharibzahedi S. M., Hernandezortega C., Weltichanes J., Putnik P., Barba F. J., Mallikarjunan K., Roohinejad S. (2019), High pressure processing of food-grade emulsion systems: Antimicrobial activity, and effect on the physicochemical properties, Food Hydrocolloids, 87, pp. 307-320.

62. Grossi A., Soltoftjensen J., Knudsen J. C., Christensen M., Orlien V. (2011), Synergistic cooperation of high pressure and carrot dietary fibre on texture and colour of pork sausages, Meat Science, 89(2), pp. 195-201.

63. Moller S. M., Grossi A., Christensen M., Orlien V., Soltoftjensen J., Straadt I. K., Thybo A. K., Bertram H. C. (2011), Water properties and structure of pork sausages as affected by highpressure processing and addition of carrot fibre, Meat Science, 87(4), pp. 387-393.

64. Chun J., Choi M., Min S., Hong G. (2014), Effects of binders combined with glucono- $\delta$-lactone on the quality characteristics of pressure-induced cold-set restructured pork, Meat Science, 98(2), pp. 158-163.

65. Hong G., Park S., Kim J., Min S. (2006), The Effects of High Pressure and Various Binders on the Physico-chemical Properties of Restructured Pork Meat, Asian-australasian Journal of Animal Sciences, 19(10), pp. 1484-1489.

66. Uresti R. M., Velazquez G., Ramirez J. A., Vazquez M., Torres J. A. (2004), Effect of highpressure treatments on mechanical and functional properties of restructured products from arrowtooth flounder (Atheresthes stomias), Journal of the Science of Food and Agriculture, 84(13), pp. 1741-1749.

67. Ngarize S., Adams A. R., Howell N. K. (2005), A co MParative study of heat and high pressure induced gels of whey and egg albumen proteins and their binary mixtures, Food Hydrocolloids, 19(6), pp. 984-996.

68. Trespalacios P., Pla R. (2009), Development of low-fat chicken meat and dried egg white gels by high pressure, High Pressure Research, 29(1), pp. 150-161.

69. Oflynn C. C., Cruzromero M. C., Troy D. J., Mullen A. M., Kerry J. P. (2014), The application of high-pressure treatment in the reduction of phosphate levels in breakfast sausages, Meat Science, 96(1), pp. 633-639.

70. Sazonova S., Grube M., Shvirksts K., Galoburda R., Gramatina I. FTIR spectroscopy studies of high pressure-induced changes in pork macromolecular structure, Journal of Molecular Structure (2019), DOI: 10.1016/j.molstruc.2019.03.038.

71. Iwasaki T., Noshiroya K., Saitoh N., Okano K., Yamamoto K. (2006), Studies of the effect of hydrostatic pressure pretreatment on thermal gelation of chicken myofibrils and pork meat patty, Food Chemistry, 95(3), pp. 474-483.

72. Hwang J. S., Lai K. M., Hsu K. C. (2007), Changes in textural and rheological properties of gels from tilapia muscle proteins induced by high pressure and setting, Food Chemistry, 104(2), pp. 746-75.

73. Mandava R., Fernandez L., Juillerat M. (1994), Effect of high hydrostatic pressure on sausage batters, 40th International Congress of Meat Science Technology. S-VIB.11. (pp. 14-16). Netherlands: The Hague.

74. Oflynn C. C., Cruzromero M. C., Troy D. J., Mullen A. M., Kerry J. P. (2014), The application of high-pressure treatment in the reduction of salt levels in reduced-phosphate breakfast sausages, Meat Science, 96(3), pp. 1266-1274.

75. Hygreeva D., Pandey M. C., Chauhan O. P. (2016), Effect of High-Pressure Processing on Quality Characteristics of Precooked Chicken Patties Containing Wheat Germ Oil Wheat Bran and Grape Seed Extract, Journal of Food Processing and Preservation, 41(3). pp. 1-13.

76. Crehan C. M., Troy D. J., Buckley D. J. (2000), Effects of salt level and high hydrostatic pressure processing on frankfurters formulated with 1.5 and 2.5\% salt, Meat Science, 55(1), pp. 123-130. 
77. Mormur M., Yuste J. (2003), High pressure processing applied to cooked sausage manufacture: physical properties and sensory analysis, Meat Science, 65(3), pp. 1187-1191.

78. Rastogi N. K., Raghavarao K. S. M. S., Balasubramaniam V. M., Niranjan K., Knorr D. (2007), Opportunities and challenges in high pressure processing of foods, Critical Reviews in Food Science and Nutrition, 47(1), pp. 69-112.

79. Carballo J., FernaÂndez P., JimeÂnez-Colmenero F. (1996), Texture of uncooked and cooked low- and high-fat meat batters as ajected by high hydrostatic pressure, Journal of Agricultural and Food Chemistry, 44, pp. 1624-1625.

80. Yang H., Khan M. A., Yu X., Zheng H., Han M., Xu X., Zhou G. (2016), Changes in protein structures to improve the rheology and texture of reduced-fat sausages using high pressure processing, Meat Science, 121, pp. 79-87.

81. Zheng H., Xiong G., Han M., Deng S., Xu X., Zhou G. (2015), High pressure/thermal combinations on texture and water holding capacity of chicken batters, Innovative Food Science and Emerging Technologies, 30, pp. 8-14.

82. Tintchev F., Bindrich U., Toepfl S., Strijowski U., Heinz V., Knorr D. (2013), High hydrostatic pressure/temperature modeling of frankfurter batters, Meat Science, 94(3), pp. 376-387.

83. Buckow R., Sikes A. L., Tume R. K. (2013), Effect of High Pressure on Physicochemical Properties of Meat, Critical Reviews in Food Science and Nutrition, 53(7), pp. 770-786.

84. Colmenero F J. (2002). Muscle protein gelation by combined use of high pressure/temperature [J]. Trends in Food Science and Technology, 13(1), pp. 22-30.

85. Cando D., Moreno H. M., Tovar C. A., Herranz B., Borderias A. J. (2014), Effect of High Pressure and/or Temperature over Gelation of Isolated Hake Myofibrils, Food and Bioprocess Technology, 7(11), pp. 3197-3207.

86. Hong G., Min S., Ko S., Choi M. (2008), Effect of high pressure treatments combined with various levels of $\kappa$-carrageenan on cold-set binding in restructured pork, International Journal of Food Science and Technology, 43(8), pp. 1484-1491.

87. Grossi A., Soltoftjensen J., Knudsen J. C., Christensen M., Orlien V. (2012), Reduction of salt in pork sausages by the addition of carrot fibre or potato starch and high pressure treatment, Meat Science, 92(4), pp. 481-489.

88. Lee H., Choe J., Yong H. I., Lee H. J., Kim H. J., Jo C. (2018), Combination of sea tangle powder and high-pressure treatment as an alternative to phosphate in emulsion-type sausage, Journal of Food Processing and Preservation, 42(9).

89. Wenting Wang, Teng Pan, Yaqi Zhang, Ying Wang, Jie Zhu, Dequan Zhang. (2019), Ultrastructure of longissimus dorsi myofibrillar proteins and heat-induced gels as observed with atomic force microscopy: effects of $\mathrm{pH}$ values and sodium ions, International Journal of Food Properties, 22, (1), pp. 34-41.

90. Sun X. D., Holley R. A. (2011), Factors Influencing Gel Formation by Myofibrillar Proteins in Muscle Foods, Comprehensive Reviews in Food Science and Food Safety, 10(1), pp. 33-51.

91. Colmenero F. J. (2002), Muscle protein gelation by combined use of high pressure/temperature, Trends in Food Science and Technology, 13(1), pp. 22-30.

92. Zhang Z., Yang Y., Zhou P., Zhang X., Wang J. (2017), Effects of high pressure modification on conformation and gelation properties of myofibrillar protein, Food Chemistry, pp. 678-686.

93. Hsu K. C., Hwang J. S., Yu C. C., Jao C. L. (2007), Changes in conformation and in sulfhydryl groups of actomyosin of tilapia (Orechromis niloticus) on hydrostatic pressure treatment, Food Chemistry, 103, pp. 560-564.

94. Lee E., Kim Y., Lee N., Hong S., Yamamoto K. (2007), Differences in properties of myofibrillar proteins from bovine semitendinosus muscle after hydrostatic pressure or heat treatment, Journal of the Science of Food and Agriculture, 87(1), pp. 40-46.

95. Ma H., Zhou G., Ledward D. A., Yu X., Pan R. (2011) Effect of Combined High Pressure and Thermal Treatment on Myofibrillar Proteins Solubilization of Beef Muscle, International Journal of Molecular Sciences, 12(5), pp. 3034-3041.

96. Barriosperalta P., Perezwon M., Tabilomunizaga G., Brioneslabarca V. (2012), Effect of high pressure on the interactions of myofibrillar proteins from abalone (Haliotis rufencens) containing several food additives, LWT-Food Science and Technology, 49(1), pp. 28-33. 


\section{- Food Technology}

97. Han M. Y., Wang P., Xu X. L., Zhou G. H. (2014), Low-field NMR study of heat-induced gelation of pork myofibrillar proteins and its relationship with microstructural characteristics, Food Research International, 62, pp. 1175-1182.

98. Yang H., Han M., Bai Y., Han Y., Xu X., Zhou G. (2015), High pressure processing alters water distribution enabling the production of reduced-fat and reduced-salt pork sausages, Meat Science, pp. 69-78.

99. Zhang Z., Yang Y., Tang X., Chen Y., You Y. (2015), Chemical forces and water holding capacity study of heat-induced myofibrillar protein gel as affected by high pressure, Food Chemistry, 188(188), pp. 111-118.

100. Iwasaki T., Noshiroya K., Saitoh N., Okano K. and Yamamoto K. (2006), Studies of the effect of hydrostatic pressure pretreatment on thermal gelation of chicken myofibrils and pork meat patty, Food Chemistry, 95, pp. 474-483.

101. Cando D., Herranz B., Borderías A. J., Moreno H. M. (2015), Effect of high pressure on reduced sodium chloride surimi gels, Food Hydrocolloids, 51, pp. 176-187.

102. Aertsen A., Meersman F., Hendrickx M. E. G., Vogel R. F., Michiels C. W. (2009), Biotechnology under high pressure: applications and implications, Trends in Biotechnology, 27(7), pp. 434-441.

103. Grossi A., Olsen K., Bolumar T., Rinnan Å., Ogendal L. H., Orlien V. (2016), The effect of high pressure on the functional properties of pork myofibrillar proteins, Food Chemistry, 196, pp. $1005-1015$.

104. Angsupanich K., Edde M., Ledward D. A. (1999), Effects of High Pressure on the Myofibrillar Proteins of Cod and Turkey Muscle, Journal of Agricultural and Food Chemistry, 47(1), pp. 92-99.

105. Ko W. C., Jao C. L., Hsu K. C. (2003), Effect of hydrostatic pressure on molecular conformation of tilapia (Orechromis niloticus) myosin, Journal of Food Science, 68(4), pp. 1192-1195.

106. Suzuki A., Suzuki N., Ikeuchi Y., Saito M. (1991), Effects of High Pressure Treatment on the Ultrastructure and Solubilization of Isolated Myofibrils, Agricultural and biological chemistry, 55(10), pp. 2467-2473.

107. Cao Y., Xia T., Zhou G., Xu X. (2012), The mechanism of high pressure-induced gels of rabbit myosin, Innovative Food Science and Emerging Technologies, 16, pp. 41-46.

108. Messens W., Van Camp J., Huyghebaert A. (1997), The use of high pressure to modify the functionality of food proteins, Trends in Food Science Technology, 8, pp. 107-112.

109. Puppo M. C., Speroni F., Chapleau N., Lamballerie M., Añón M. C., Anton M. (2005), Effect of high-pressure treatment on emulsifying properties of soybean proteins, Food Hydrocolloids, 19, pp. 289-296.

110. Speroni F., Szerman N., Vaudagna S. R. (2014), High hydrostatic pressure processing of beef patties: Effects of pressure level and sodium tripolyphosphate and sodium chloride concentrations on thermal and aggregative properties of proteins, Innovative Food Science and EmergingTechnologies, 23, pp. 10-17.

111. Chapleau N. J., de Lamballerie-Anton M. I. (2003), Changes in myofibrillar proteins interactions and rheological properties induced by high-pressure processing, European Food Research and Technology, 216, pp. 470-476.

112. Zhang H. K., Li L., Tatsumi E., Kotwal S. (2003), Influence of high pressure on conformational changes of soybean glycinin, Innovative Food Science and Emerging Technologies, 4, pp. 269 275.

113. Berhe D. T., Engelsen S. B., Hviid M. S., Lametsch R. (2014), Raman spectroscopic study of effect of the cooking temperature and time on meat proteins, Food Research International, pp. $123-131$. 